\title{
Geo-electric assessment for groundwater potential at permanent site of Waziri Umaru Federal Polytechnic, Birnin Kebbi, Kebbi State North Western, Nigeria
}

\author{
Ibrahim Mohammed $^{1 *}$ and Suleiman Taofiq ${ }^{2}$ \\ 1Department of Preliminary Studies, Waziri Umaru Federal Polytechnic Birnin Kebbi, Nigeria. \\ 2Department of Science Education, Waziri Umaru Federal Polytechnic Birnin Kebbi, Nigeria. \\ ${ }^{*}$ Corresponding author. Email: ibrahimmohd628@gmail.com
}

Copyright (C) 2021 Mohammed and Taofiq. This article remains permanently open access under the terms of the Creative Commons Attribution License 4.0, which permits unrestricted use, distribution, and reproduction in any medium, provided the original work is properly cited.

Received 27th August, 2020; Accepted 6th October, 2020

\begin{abstract}
Vertical Electrical Soundings (VES) afford fast and economical measurements used in geophysical exploration. VES was used for groundwater exploration at the permanent site of Waziri Umaru Federal Polytechnic, Birnin Kebbi. Eighteen (18) Vertical Electrical Sounding (Schlumberger array, maximum AB/2 distance $100 \mathrm{~m}$ ) were performed, data were acquired using ABEM terrameter (SAS 300c), to determine the geoelectric units in the subsurface stratigraphy as well as to delineate groundwater potential in the area via electrical resistivity soundings. Field data collected was analyzed using computer software (IPI2win) which gives an automatic interpretation of the apparent resistivity in ohmmeter. Data was interpreted in terms of the resistivity and thickness of subsurface layers. Results indicates that three to five (3-5) distinct layers in the study area namely; top soil which is mainly sand, clayey sand/loose sand, sandy clay/fine sand and clay unit were delineated. The result also revealed that water bearing formation exists in the third layer in some identified VES locations i.e VES 3, VES5, VES13 and VES14 with very good aquifers, with thickness and corresponding resistivity values of $40.5,37.5,45.8,60 \mathrm{~m}$ and $173,148,222$ and $432 \Omega \mathrm{m}$ respectively. The electrical resistivity data, therefore gives reasonable accurate results that can be used to understand stratigraphy and sedimentary configuration in ground water exploration.
\end{abstract}

Keywords: Exploration, geophysical, resistivity, thickness, vertical electrical sounding.

\section{INTRODUCTION}

Electrical resistivity method in geophysical exploration for groundwater in a sedimentary environment has proven reliable (Alile et al., 2011). In the sedimentary terrain, permeable and porous rock masks such as sandstone and loose sands are good indicators of aquifer and these are often characterized by relatively low resistivity (Odunaike et al., 2013). There are various techniques employed in groundwater exploration (gravity, magnetics, seismic, electrical and electromagnetic methods), electrical resistivity method is reliable in delineating zones of relatively low resistivity which might be a signatory of saturated strata in various geophysical terrain (Oyedele and Olayinka, 2012; Olasehinde et al., 2015).
Groundwater is the largest available reservoir of fresh water (Adepelumi et al., 2013). Groundwater is of significant importance to northern Nigeria where the amount of rainfall is limited to very few months of the year with annual rainfall of 1000 to $1500 \mathrm{~mm}$ and surface water sources are usually inadequate (Olasehinde et al., 2015). Water is of significant importance not only for human survival, but also for every development. It is used for various purposes which include domestic, irrigation, industrial, power generation and recreation. The amount of surface water available for domestic, industrial and agricultural use is insufficient to fulfill the current demand in the world (Abdullahi and Iheakanwa , 2013). The 
development of groundwater resources for potable use has increased substantially over the last two decades in developing countries as a result of rapid expansion of cities and subsequent population explosion (Awonusi et al., 2008).

The study area is threatened by increasing population trend due to continuous evacuation of students and staff from the temporary site to permanent site of the institution. However, groundwater research in Kebbi State does not seem to be growing at the same rate with its high demand as a result of population explosion which to a large extent is a major challenge for future development of groundwater in the State. Due to the population increase, urbanization, industrialization and extreme agricultural activities in Kebbi State in particular and Nigeria in general, the requirement for groundwater has increased immensely in recent years. Vertical Electrical Sounding widely used as highlighted by various researchers (Fadele et al., 2013; Odunaike et al.,2013; Musa et al.,2014; Yelwa et al., 2015; Omeje et al., 2015; Olasehinde et al., 2015; Murtala, 2016; Emanuel et al., 2017; Umar et al., 2017; Usman, 2019; Adebo et al., 2018). The study aimed at using electrical resistivity method to determine the groundwater potential of a permanent site of Waziri Umaru Federal Polytechnic, Birnin Kebbi with view to (i) determine the resistivity at different earth's layers (ii) obtain the thickness of the earth's layers (iii) present the resistivity patterns at designated layer (iso-resistivity contour maps) and (iv) determine the depth to basement.

\section{LOCATION, METEOROLOGY AND GEOLOGY OF THE STUDY AREA}

The study area lies within the sedimentary region of northern Nigeria between latitudes $12^{\circ} 27.454^{\prime} \mathrm{N}$ to $12^{\circ} 28.239^{\prime} \mathrm{N}$ and longitudes $004^{\circ} 13.624^{\prime} \mathrm{E}$ to $004^{\circ} 14.874^{\prime} \mathrm{E}$ in Birnin Kebbi metropolis between latitude $12^{\circ} 27.13^{\prime} \mathrm{N}$ and longitude $4^{\circ} 12.01^{\prime} \mathrm{E}$ of Kebbi State between latitude $10^{\circ} \mathrm{N}$ to $13^{\circ} \mathrm{N}$ and longitude $3^{\circ} \mathrm{E}$ to $6 \mathrm{E}$ in north-western Nigeria.

The Kebbi State belongs to the savanna climate, and the rainy season and the dry season are clear. The rainy season is from May to October, and the dry season is from November to April. Between December and March, it hardly rains with mean monthly precipitation of almost 0 $\mathrm{mm}$, though the annual mean precipitation is $835 \mathrm{~mm}$. The annual average minimum temperature is $22.2^{\circ} \mathrm{C}$, and the annual average maximum temperature is $34.7^{\circ} \mathrm{C}$ (JICA, 2011).

The study area Birnin Kebbi (Figure 1) is dominated by two formations; Precambrian Basement Complex in the southern and south east and young sedimentary rocks in the north. In the Basement Complex, gneiss is distributed in large area and the schist and granite is distributed in narrow area. In the Cretaceous, the argillaceous strata with intercalated sandstone layers are predominant in the lower part of the Cretaceous, and sandstone strata become thick in the upper part of the Cretaceous. In the Tertiary, the argillaceous strata are predominant in the lower part of the Tertiary, and the sandstone layers are intercalated in the upper part of the Tertiary. The alluvial deposit of Quaternary is distributed over the lowlands along big rivers such as Niger River and Sokoto River, with the small thickness of the deposit. It is presumed that the aquifer consists of (i) the weathered and fractured part of the Basement Complex, (ii) the sandstone and the fractured part of the Cretaceous, and (iii) the sandstone layers of the Tertiary (JICA, 2011).

\section{MATERIALS AND METHOD}

The materials used for the Vertical Electrical Sounding (VES) includes: the Global Positioning System (GPS), ABEM Terrameter (SAS 300c), connecting cables, four electrodes (steel rods), measuring tapes and hammers. The IP2Win software was used for analyzing geo-electrical data. Vertical Electrical Sounding (VES) was carried out at eighteen (18) different points using Schlumberger configuration with electrode spread at maximum $A B / 2=$ $100 \mathrm{~m}$. The fixed point was chosen and an iron rod was driven into the ground with the aid of hammer. This marks the VES station which was used as a mid-point from where half current electrodes spacing $(A B / 2)$ and half potential electrodes spacing (MN/2) were measured in opposite directions using the marked mid-point and measuring tape. Two current electrodes ( $\mathrm{C} 1$ and $\mathrm{C} 2$ ) of equal distance on the opposite sides of the VES station were measured and driven into the ground with the aid of hammer for proper contact to be made with the ground. Similarly, two potential electrodes $\left(P_{1}\right.$ and $\left.P_{2}\right)$ of equal distance and between the current electrodes were measured and driven into the ground. The measurements were repeated and recorded with $M N / 2$ fixed at its initial distance and $A B / 2$ was symmetrically increased. Whenever the resistance measured becomes low, then $\mathrm{MN} / 2$ was also increased symmetrically. The arrangements of the current and potential electrodes were made in such a way as to maintain a straight line. These pairs of electrodes were connected to the Terrameter through points $A B$ and $M N$ (Figure 2a), which referred to as Schlumberger configuration, in which the inner potential electrodes have a spacing $2 \mathrm{l}$ which is a small proportion of that of the outer, currents electrodes (2L). In a case where the current sink is a finite distance from the source (Figure 2). The potential $V c$ at an internal electrode $C$ is the sum of the potential contributions $V_{A}$ and $V_{B}$ from the current source at $A$ and the sink at $B$.

$$
\begin{aligned}
& \mathrm{V}_{\mathrm{C}}=\mathrm{V}_{\mathrm{A}}+\mathrm{V}_{\mathrm{B}} \\
& V_{C}=\frac{P \mathrm{I}}{2 \pi}\left(\frac{I}{r_{A}}-\frac{I}{r_{B}}\right)
\end{aligned}
$$

Similarly, 


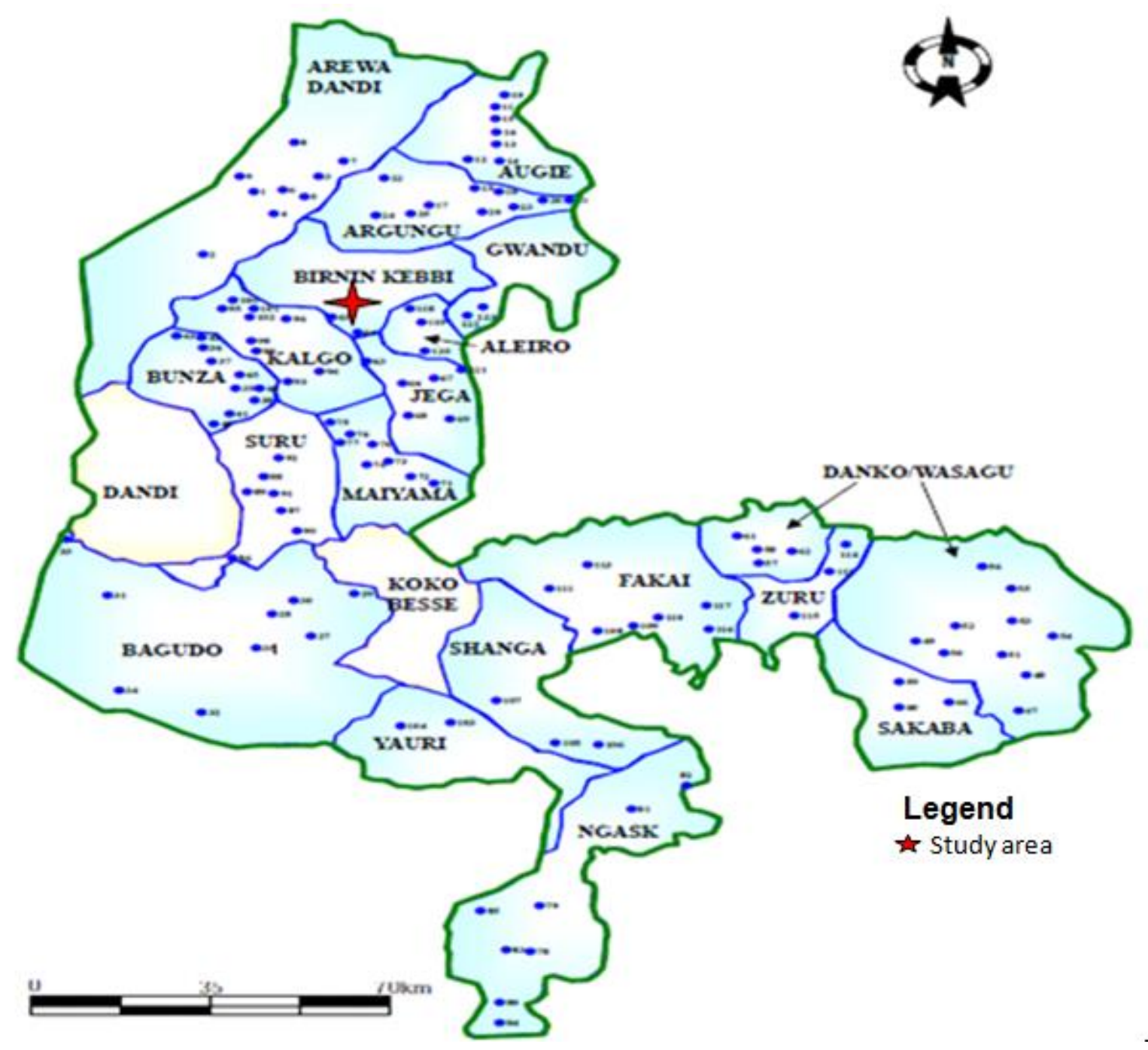

Figure 1. Location of study area (JICA, 2011).

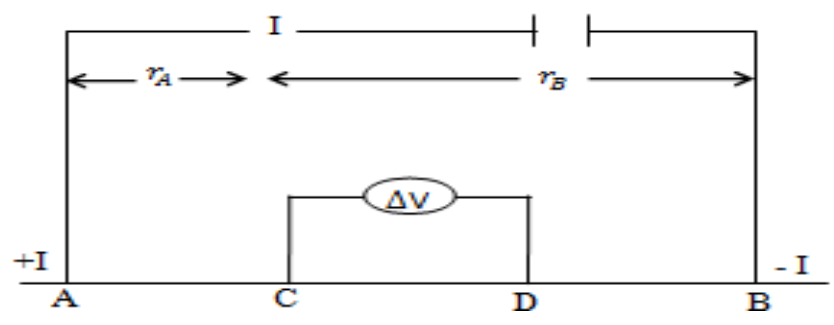

Figure 2. The generalized form of electrode configuration.

$V_{D}=\frac{\rho \mathrm{I}}{2 \pi}\left(\frac{I}{R_{A}}-\frac{I}{R_{B}}\right)$

Thus

$\rho=\frac{2 \pi \Delta V}{I\left\{\left(\frac{1}{r_{A}}-\frac{1}{r_{B}}\right)-\left(\frac{1}{R_{A}}-\frac{1}{R_{B}}\right)\right\}}$
Substitution of this condition into equation (3)

$\rho_{a}=\frac{\pi}{21} \frac{\left(L^{2}-x^{2}\right)}{\left(L^{2}-x^{2}\right)} \frac{\Delta V}{I}$

Where $\rho_{a}=$ apparent resistivity

\section{RESULTS AND DISCUSSION}

The results of the geoelectrical survey were presented in Tables 1, 2 and 3 . The 2D view of the geo-electric parameters (resistivity and thickness) obtained from the analysis of the electrical resistivity data obtained (Figure 3 and Appendix Figure 1) were used to adjudge the aquiferous or non aquiferous layers and expected geologic formations. The resistivity variations exist across lithologic interfaces or geo-electric boundaries in the subsurface. The interpreted result revealed three to five geoelectric 
Table1. Geoelectric parameters of VES 1 to 6.

\begin{tabular}{|c|c|c|c|c|c|c|}
\hline Coordinates & VESno. & Layer no. & Resistivity $(\Omega \mathrm{m})$ & Thickness (m) & Depth (m) & Curve Types \\
\hline & \multirow{5}{*}{1} & 1 & 884 & 0.7 & 0.7 & \multirow{5}{*}{$\mathrm{KH}$} \\
\hline $12^{0} 27.904^{\prime} \mathrm{N}$ & & 2 & 9172 & 1.6 & 2.3 & \\
\hline 004ํ⒕392'E & & 3 & 1441 & 14.6 & 16.9 & \\
\hline \multirow[t]{2}{*}{ Elevation:744 } & & 4 & 18 & 22.1 & 39 & \\
\hline & & 5 & 3593 & $\ldots$ & $\ldots$ & \\
\hline \multirow{4}{*}{$\begin{array}{l}12^{0} 27.952 ' \mathrm{~N} \\
004^{0} 14.365^{\prime} \mathrm{E} \\
\text { Elevation:734 }\end{array}$} & \multirow{4}{*}{2} & 1 & 1738 & 0.9 & 0.9 & \multirow{4}{*}{$\mathrm{KH}$} \\
\hline & & 2 & 6595 & 8.2 & 9.1 & \\
\hline & & 3 & 60 & 13.2 & 22.3 & \\
\hline & & 4 & 1362 & $\ldots$ & $\ldots$ & \\
\hline $12^{0} 28.005^{\prime} \mathrm{N}$ & \multirow{4}{*}{3} & 1 & 496 & 0.8 & 0.8 & \multirow{4}{*}{$\mathrm{KQ}$} \\
\hline $004^{0} 14.351^{\prime} \mathrm{F}$ & & 2 & 14876 & 3.7 & 4.6 & \\
\hline \multirow{2}{*}{ Elevation: 734} & & 3 & 173 & 40.4 & 45 & \\
\hline & & 4 & 4.18 & $\ldots$ & $\ldots$ & \\
\hline $12^{0} 28.058^{\prime} \mathrm{N}$ & \multirow{3}{*}{4} & 1 & 994.7 & 0.3 & 0.3 & \multirow{3}{*}{$\mathrm{K}$} \\
\hline $004^{0} 14.351^{\prime} \mathrm{E}$ & & 2 & 2638 & 13.4 & 13.8 & \\
\hline Elevation: 726 & & 3 & 128.9 & $\ldots$ & $\ldots$ & \\
\hline & \multirow{4}{*}{5} & 1 & 782 & 0.5 & 0.5 & \multirow{4}{*}{$\mathrm{KH}$} \\
\hline $12^{0} 28.112^{\prime} \mathrm{N}$ & & 2 & 2868 & 9.5 & 10 & \\
\hline \multirow{3}{*}{ Elevation: 704} & & 3 & 148 & 37.5 & 47.5 & \\
\hline & & 4 & 13389 & en & $\ldots$ & \\
\hline & & 1 & 412 & 0.4 & 0.4 & \multirow{5}{*}{$\mathrm{HKH}$} \\
\hline $12^{0} 28.167^{\prime} \mathrm{N}$ & & 2 & 9867 & 0.5 & 0.9 & \\
\hline $004^{0} 14.337^{\prime} \mathrm{E}$ & 6 & 3 & 1247 & 9.6 & 10.4 & \\
\hline \multirow[t]{2}{*}{ Elevation: 716} & & 4 & 289 & 31.7 & 42.2 & \\
\hline & & 5 & 0.69 & & & \\
\hline
\end{tabular}

Table 2. Geoelectric parameters of VES 7 to 12.

\begin{tabular}{|c|c|c|c|c|c|c|}
\hline Coordinates & VESno. & Layer no. & Resistivity $(\Omega m)$ & Thickness (m) & Depth (m) & Curve types \\
\hline $\begin{array}{l}12^{0} 27.920^{\prime} \mathrm{N} \\
004^{0} 14.445^{\prime} \mathrm{E} \\
\text { Elevation:726 }\end{array}$ & 7 & $\begin{array}{l}1 \\
2 \\
3 \\
4\end{array}$ & $\begin{array}{c}513 \\
8505 \\
950 \\
1.23\end{array}$ & $\begin{array}{c}0.7 \\
1.1 \\
27.1\end{array}$ & $\begin{array}{c}0.7 \\
1.8 \\
28.8\end{array}$ & $\mathrm{KQ}$ \\
\hline $\begin{array}{l}12^{0} 27.9711^{\prime} \mathrm{N} \\
004^{0} 14.428^{\prime} \mathrm{E} \\
\text { Elevation: } 731\end{array}$ & 8 & $\begin{array}{l}1 \\
2 \\
3 \\
4 \\
5\end{array}$ & $\begin{array}{c}884.7 \\
12292 \\
1296 \\
351.9 \\
1.31\end{array}$ & $\begin{array}{c}0.5 \\
0.6 \\
13.7 \\
25.9\end{array}$ & $\begin{array}{c}0.5 \\
1.1 \\
14.9 \\
40.8\end{array}$ & $\mathrm{HKH}$ \\
\hline $\begin{array}{l}12^{0} 28.024^{\prime} \mathrm{N} \\
004^{0} 14.409^{\prime} \mathrm{E} \\
\text { Elevation: } 730\end{array}$ & 9 & $\begin{array}{l}1 \\
2 \\
3 \\
4\end{array}$ & $\begin{array}{c}382 \\
1781 \\
962 \\
13\end{array}$ & $\begin{array}{c}0.5 \\
5.4 \\
19.6\end{array}$ & $\begin{array}{c}0.5 \\
5.9 \\
25.5\end{array}$ & $\mathrm{KQ}$ \\
\hline
\end{tabular}


Table 2 Contd. Geoelectric parameters of VES 7 to 12.

\begin{tabular}{|c|c|c|c|c|c|c|}
\hline \multirow{4}{*}{$\begin{array}{l}12^{0} 28.075^{\prime} \mathrm{N} \\
004^{0} 14.396^{\prime} \mathrm{E} \\
\text { Elevation: } 727\end{array}$} & \multirow{4}{*}{10} & 1 & 445 & 0.5 & 0.5 & \multirow{4}{*}{$\mathrm{KQ}$} \\
\hline & & 2 & 2725 & 2.9 & 3.4 & \\
\hline & & 3 & 1194 & 18.7 & 22.1 & \\
\hline & & 4 & 33.3 & & & \\
\hline & & 1 & 775 & 1.1 & 1.1 & \\
\hline $12^{0} 28.132^{\prime} \mathrm{N}$ & & 2 & 8312 & 1.5 & 2.5 & \\
\hline 004014.392'E & 11 & 3 & 1080 & 8.0 & 10.6 & $\mathrm{HKH}$ \\
\hline \multirow[t]{3}{*}{ Elevation: 720} & & 4 & 308 & 37.9 & 48.4 & \\
\hline & & 5 & 1.99 & & & \\
\hline & & 1 & 1307 & 1.0 & 1.0 & \multirow{5}{*}{$\mathrm{HKH}$} \\
\hline $12^{0} 28.186^{\prime} \mathrm{N}$ & & 2 & 5633 & 0.5 & 1.4 & \\
\hline $004^{0} 14.389^{\prime} \mathrm{E}$ & 12 & 3 & 1269 & 11.4 & 12.8 & \\
\hline \multirow[t]{2}{*}{ Elevation: 670} & & 4 & 265 & 38.1 & 50.9 & \\
\hline & & 5 & 0.78 & & & \\
\hline
\end{tabular}

Table 3. Geoelectric parameters of VES 13 to 18.

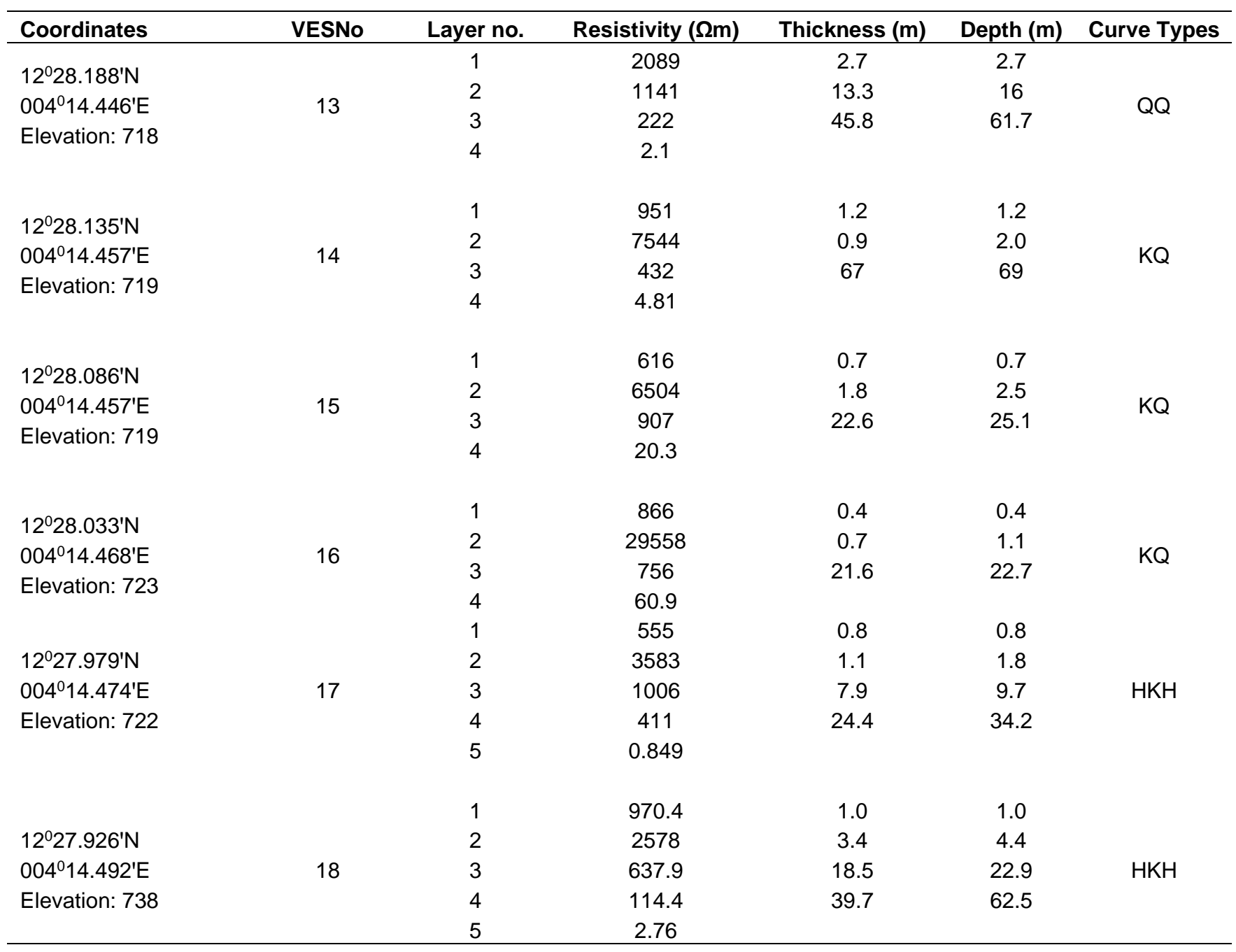



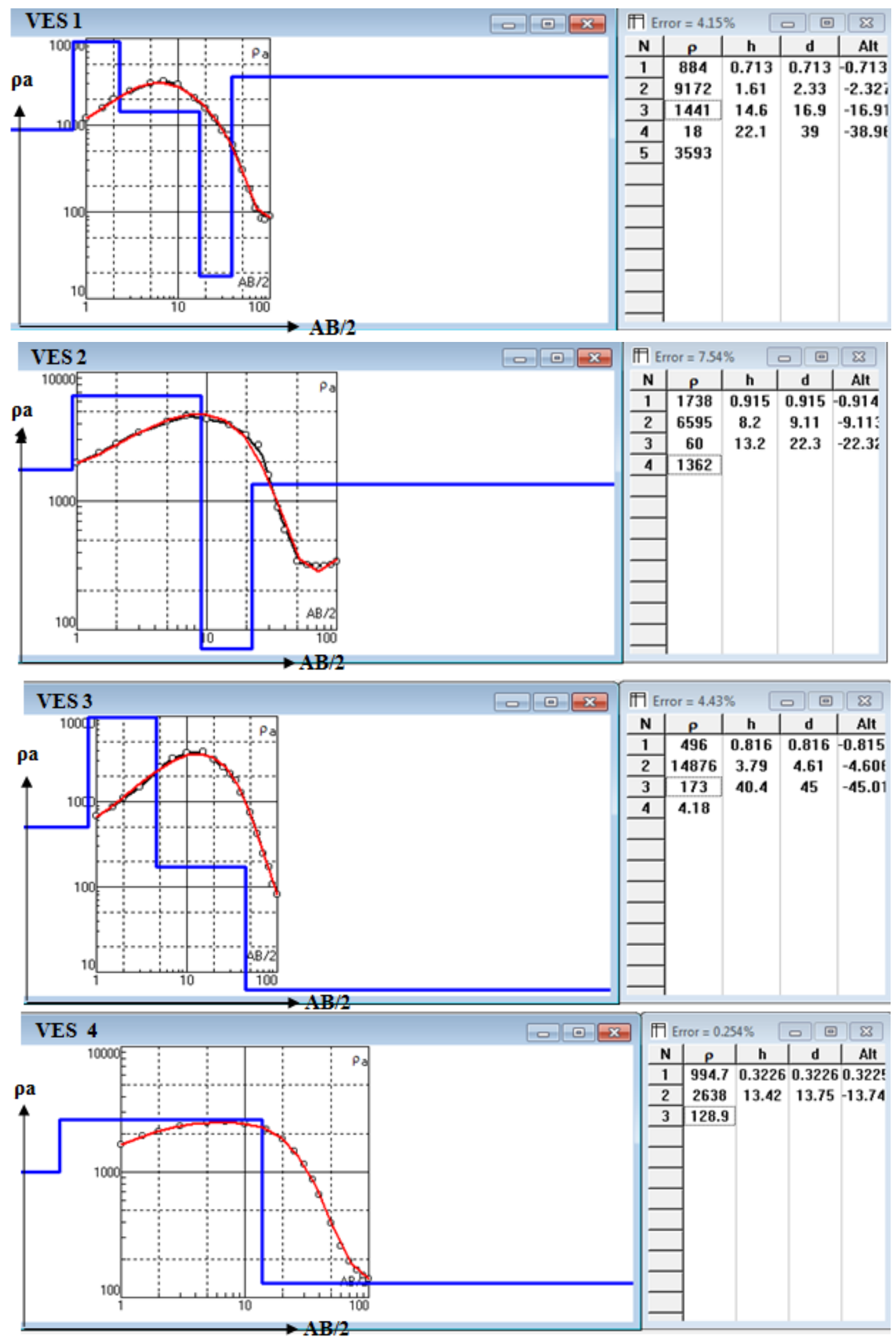

Figure 3. Model VES Curves of 4 Locations VES 1, VES 2, VES 3, and VES 4. 


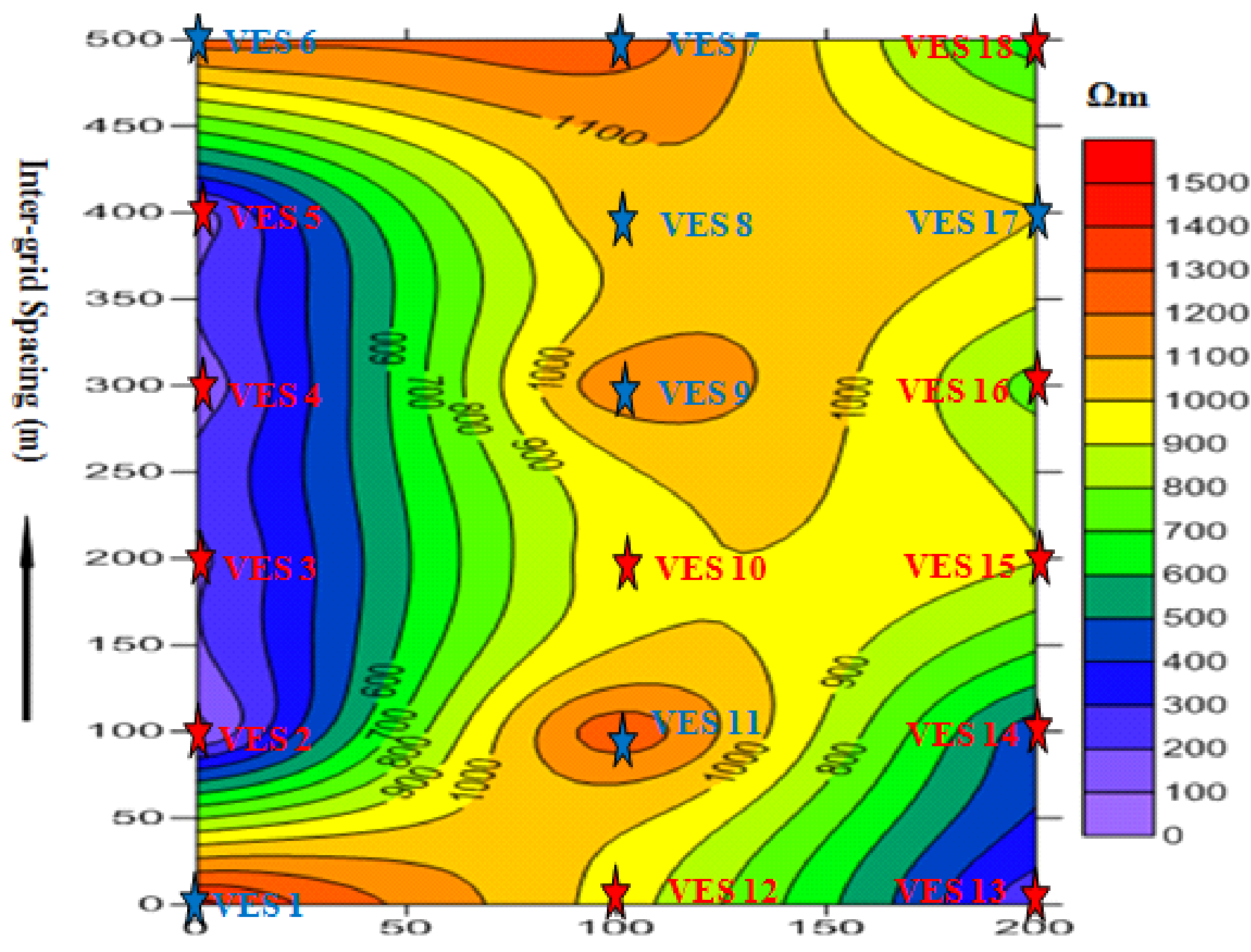

Inter-profile Spacing (m)

Figure 4. Iso-resistivity contour map of the aquifer layer.

layers in the study area. The first layer shows the diversity of resistivity and thickness ranging from 383 to $2089 \Omega \mathrm{m}$ and 0.3 to $2.7 \mathrm{~m}$ classified as top soil. The resistivity value of the second layer ranges between 1141 to $29558 \Omega \mathrm{m}$ with thickness between 0.5 to $13.4 \mathrm{~m}$ and interpreted as clayey sand/loose sand formation. The third layer with resistivity range of 60 to $1441 \Omega \mathrm{m}$ and thickness varies from $7.9 \mathrm{~m}$ to infinity. The layer interpreted as sandy clay/find sand. The fourth layer resistivity ranges between 1.23 to $13389 \Omega \mathrm{m}$ and thickness from $2.1 \mathrm{~m}$ to infinity, the layer interpreted as clay formation. The fifth layer exists in VES 1, VES 6, VES 8, VES 11, VES 12, VES 17 and VES 18 with infinite thickness, which indicates medium grain sand and sandstone formation. The fourth and fifth layers have a very low resistivity values in some part of the study area which attribute to the presence of saturated clay (Oyedele and Olayinka, 2012; Olasehinde et al., 2015). Due to the decrease in resistivity values in the third layer compared to the second layer in some areas, this show that third layer delineate a probable water saturation zone (Odunaike et al.,2013). The depth of the aquifer in third layer ranged between 9.1 to $69 \mathrm{~m}$ in some VES stations. This value is comparable to those of JICA (2011) and Usman (2019).

Iso-resistivity analysis gives the qualitative interpretation that represents the variations in resistivity at a designated depth and indicates the general lateral changes in the electrical properties around the area (Mohammed et al., 2014). Figure 5 and 6 shows the iso-resistivity and isodepth contour maps of the aquifer layer. The depth contour maps support claim of which points may have high groundwater yield due to the appreciable values of overburden thickness. Iso-resistivity and Iso-depth contour maps of aquifer layer reveal VES 3 , VES 5 , VES 13 and VES 14 are rated as best locations for groundwater exploration (Figure 4 and 5). 


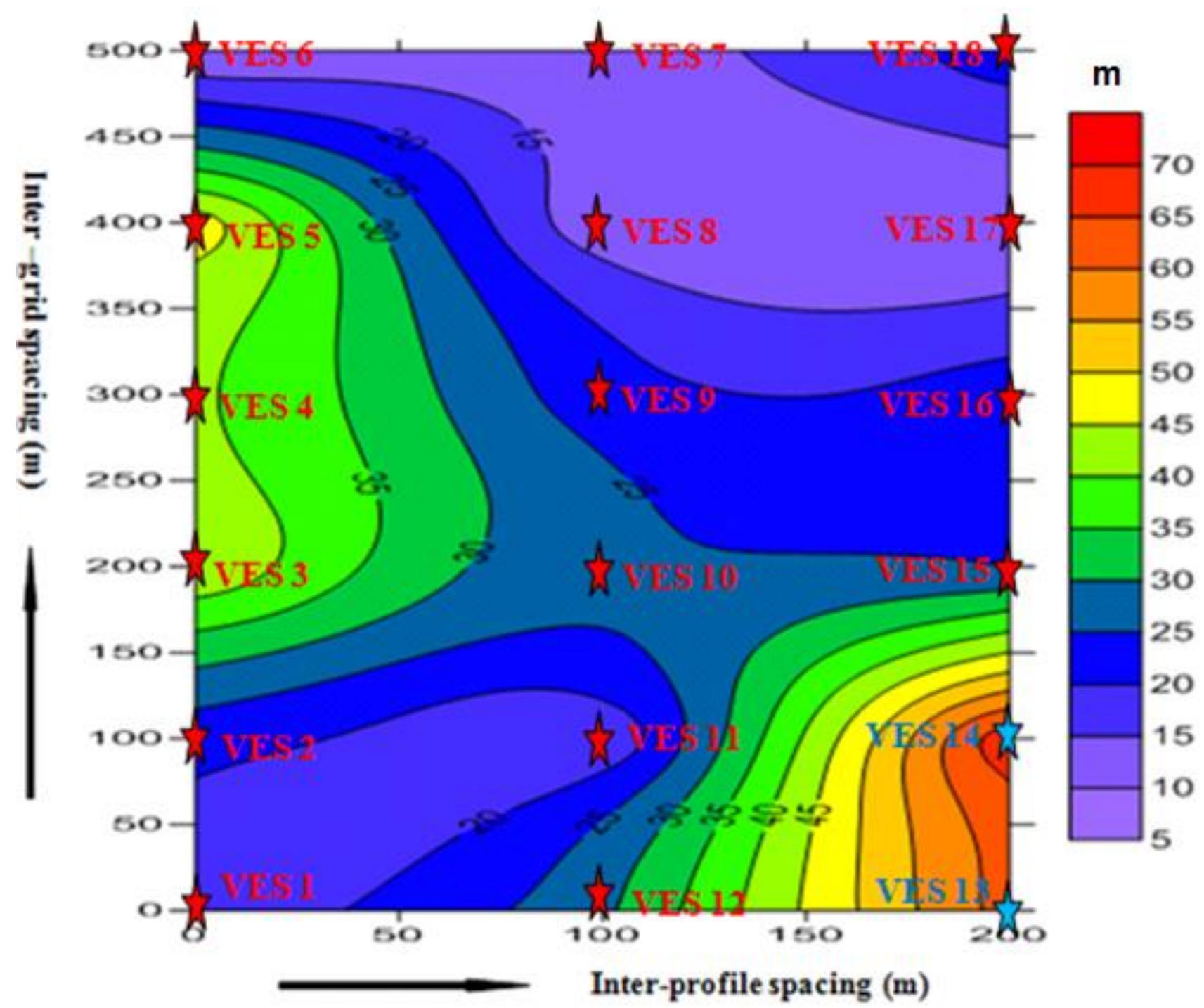

Figure 5. Iso-depth contour map of the aquifer layer.

\section{Conclusion}

Qualitative interpretation of the vertical Electrical Sounding (VES) for groundwater exploration at the permanent site of Waziri Umaru Federal Polytechnic, Birnin Kebbi, Kebbi State, North Western Nigeria, delineated a network of probable features, suspected to be groundwater occurrence as well as presence of low resistivity below 100 $\Omega m$ which serve as good indication of closeness of static water table in most of the VES stations. Different parameters, particularly resistivity and thickness of subsurface layers and their lithologic boundaries were determined and it was observed that there were variations in the levels of groundwater potential from one part of the study area to another. Good prospects therefore exist for groundwater potential within the study area where the depth to bedrock is relatively thick and has favorably low resistivity value, while those with thin depth to bedrock and high resistivity value have a lower potential for groundwater. The VES results of the entire area revealed various depth to strike the top of the water bearing zones ranged between 9.1 to $69 \mathrm{~m}$. Iso-resistivity and Iso-depth contour maps of aquifer layer revealed VES 3, VES 5, VES 13 and VES 14 as best location for groundwater exploration. The geological formation in the study area consists of: top soil which is mainly sand, clayey sand/loose sand, sandy clay/fine sand and clay unit. Furthermore, the results obtained from the survey indicate the efficiency of Vertical Electrical Sounding (VES) techniques in probing groundwater potential in the sedimentary region.

\section{Recommendation}

The use of other geophysical methods, such as the seismic, magnetic and electromagnetic methods, especially 
integrated geophysical investigation could be employed to prove the present outcome. The future boreholes in the study area should be drilled to a maximum depth of $69 \mathrm{~m}$.

\section{CONFLICT OF INTEREST}

The authors declare that they have no conflict of interest.

\section{ACKNOWLEDGEMENT}

This work was supported by the Tertiary Education Trust Fund (TET Fund).

\section{REFERENCE}

Abdullahi, N. K., \& Iheakanwa A. (2013), Groundwater detection in basement complex of northwestern Nigeria using 2D electrical resistivity and offset Wenner techniques. International Journal of Science and Technology, 7(2), 529533

Adebo, A. B, Stephen, I. O., \& Folorunso, O. E. (2018). Modeling of groundwater potential using vertical electrical sounding (VES) and multi-caterial analysis at Omitogun Housing Estate, Akure, southwestern Nigeria. Asian Journal of Advanced Research and Reports, 1(2), 1-11.

Adepelumi, A. A. Akinmade, O. B., \& Fayemi, O. (2013). Evaluation of Groundwater Potential of Baikin Ondo State Nigeria Using Resistivity and Magnetic Techniques: A case study. Universal Journal of Geoscience, 1(2), 37-45.

Alile, O. M., Ujuanbi, O., \& Evbuomwan, I. A. (2011), Geoelectric investigation of groundwater in Obaretin - lyanomon locality, Edo state, Nigeria. Journal of Geology and Mining Research, 3(1), 13-20.

Awonusi, A., Orebiyi, O., \& Oyedokun, O. (2008), Geophysical investigations for groundwater exploration in a crystalline basement, southwest Nigeria, New York Science Journal, p. 19-35. Retrieved from http://www.sciencepub.net/newyork/ 0104/04_0453_Awonusi_Geophysical.pdf.

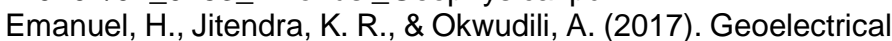
survey of ground water in some parts of Kebbi State Nigeria: Case sudy of Federal Polytechnic bye-pass, Birnin Kebbi and Magoro Primary Health Center, Fakai Local Government. Geosciences, 7(5), 141-149.

Fadele, S. I., Sule, P. O., \& Dewu, B. B. M. (2013). The use of vertical electrical sounding (VES) for groundwater exploration around Nigerian college of aviation technology (NCAT), Zaria, Kaduna State, Nigeria. Pacific Journal of Science and Technology, 14(1), 549-555.
Japan International Cooperation Agency (JICA) (2011). Preparatory survey on the project for improvement of rural water supply in the Federal Republic of Nigeria. Final Report. $\mathrm{Pp}$.1.1-1.4.

Mohammed, G., Ibrahim, A., Hassan, A., Ibrahim, S., Mahdy, A., Ibrahim, M., Bektas, S., Mohammed, G., \& Ibrahim, A. (2014). Geo-electrical data analysis to demarcate groundwater pocket zones in Kaltungo and environes, northeastern Nigeria. International Journal of Engineering, 4(11), 8269.

Murtala, A. G. (2016). An investigation of groundwater potential of Gada town, Sokoto State using vertical electrical sounding (VES). Master's Thesis, Ahmadu Bello University Zaria, Nigeria. The Pacific Journal of Science and Technology, 14(1), 540-550.

Musa, G. A., Mohd, E. T., \& Barzani, M. G. (2014). The application of vertical electrical sounding (VES) for groundwater exploration in Tudun Wada Kano State, Nigeria. International Journal of Engineering Research and Reviews, 2(4), 51-55.

Odunaike, R. K., Akinyem L. P., Oyekunle A., \& ljeoma G. C. (2013), Application of vertical electrical method in groundwater exploration at Remo North Local Government in Ogun State of Nigeria. Journal of Emerging Trends in Engineering and Applied Sciences, 4(4), 672-678.

Olasehinde, A., Sulaiman, A., Bute S. I., \& Hamza, Y. S. (2015), Hydro geophysical investigation of Kushi and its environs, northeastern, Nigeria. International journal of research in Geography, 1(1), 13-21.

Omeje, M., James, E. E., \& Ekene, P. U. (2015). Geophysical analysis of basement terrain groundwater using vertical electrical sounding: A case study of parts of Abuja North Central Nigeria. International Journal of Geophysics and Geochemistry, 2(4), 92-97.

Oyedele, E. A. A., \& Olayinka, A. I. (2012), Statistical evaluation of groundwater potential of Ado-Ekiti, Southwest, Nigeria. Transnational Journal of Science and Technology, 2(6), 110127.

Umar, A. B., Ladan, B., \& Gado, A. A. (2017). Groundwater evaluation study using electrical resistivity measurements in Bunza area of Kebbi State, Nigeria. International Journal of Environment and Bioenergy, 12(2), 100-114.

Usman, Z. M. (2019), Geoelectric survey for groundwater exploration at Birnin-Kebbi, Kebbi State, Nigeria. FUDMA Journal of Sciences, 3(1), 168-178

Yelwa, N. A., Hamidu, H., Falalu, B. H., Kana, M. A., \& Madabo, I. M. (2015). Groundwater prospecting and aquifer delineation using vertical electrical sounding (VES) method in the basement complex terrain of Kumbotso LGA of Kano State Nigeria. Journal of Applied Geology and Geophysics, 3(1), 01 06. 


\section{Appendix}

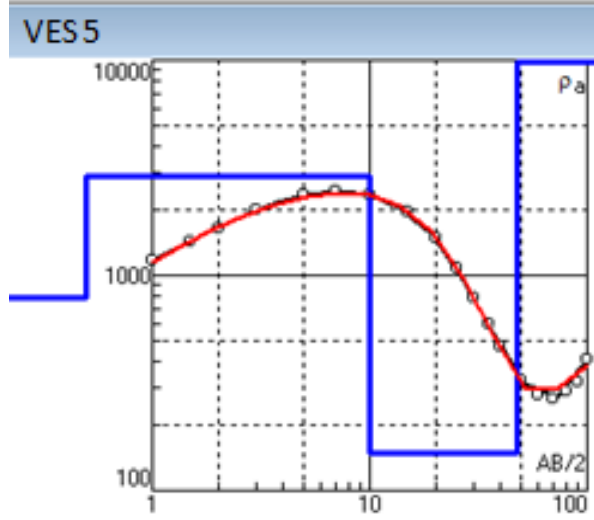

VES 6

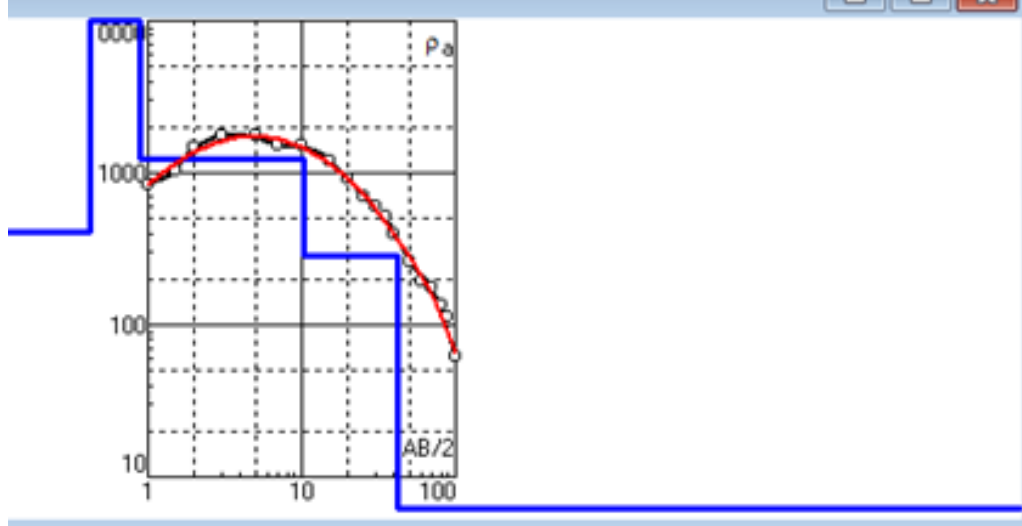

VES 7
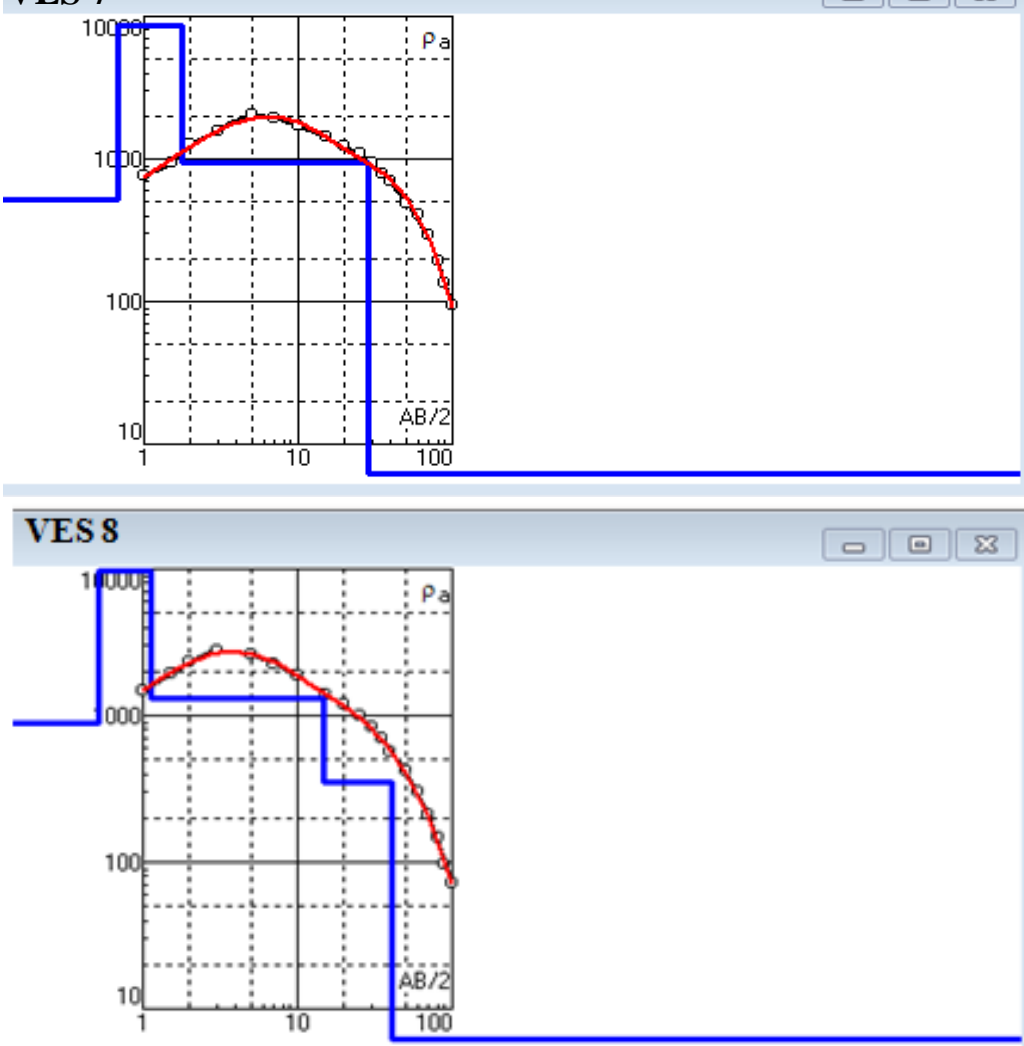

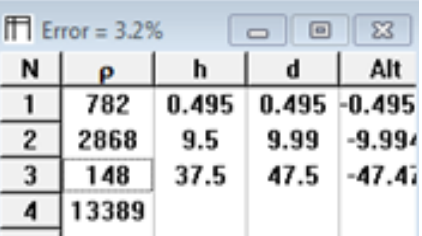

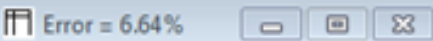

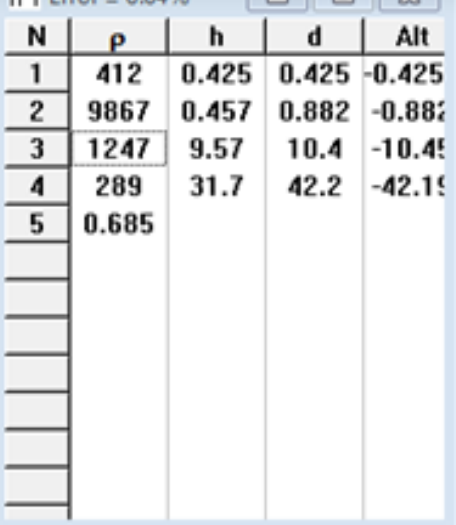

用 Error $=3.93 \% \quad \square \quad$ 回
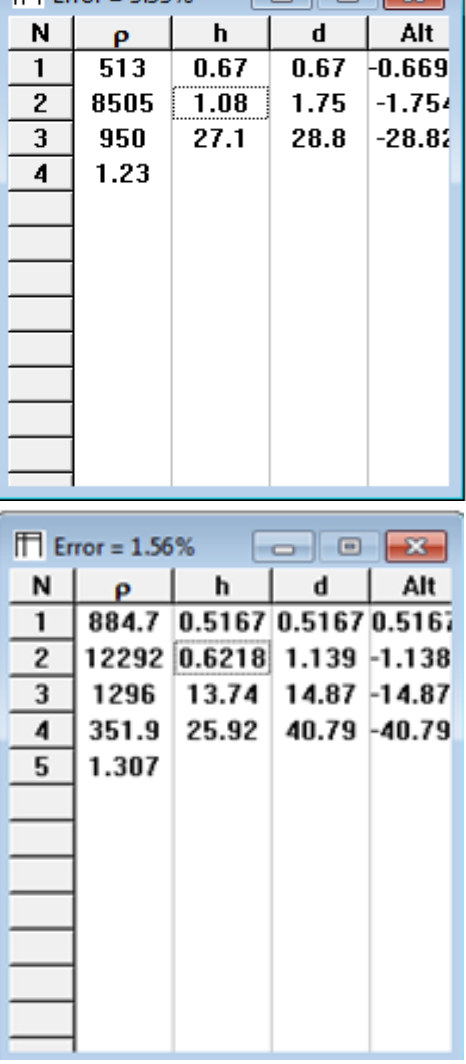

Appendix Figure 1. Model VES Curves of 4 Locations VES 5 - VES 8. 


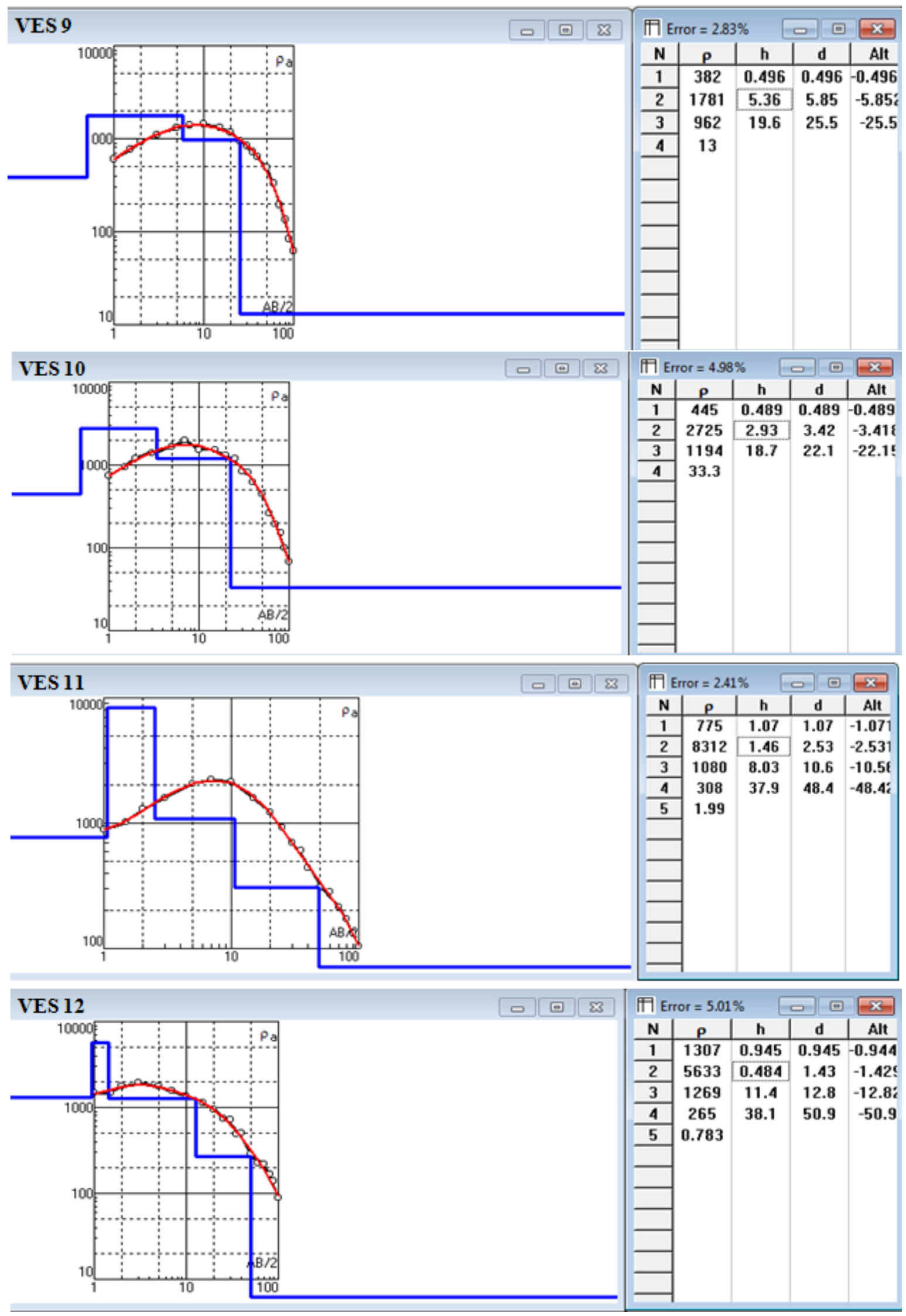

Appendix Figure 1 Contd. Model VES curves of 4 locations VES 9 - VES 12. 

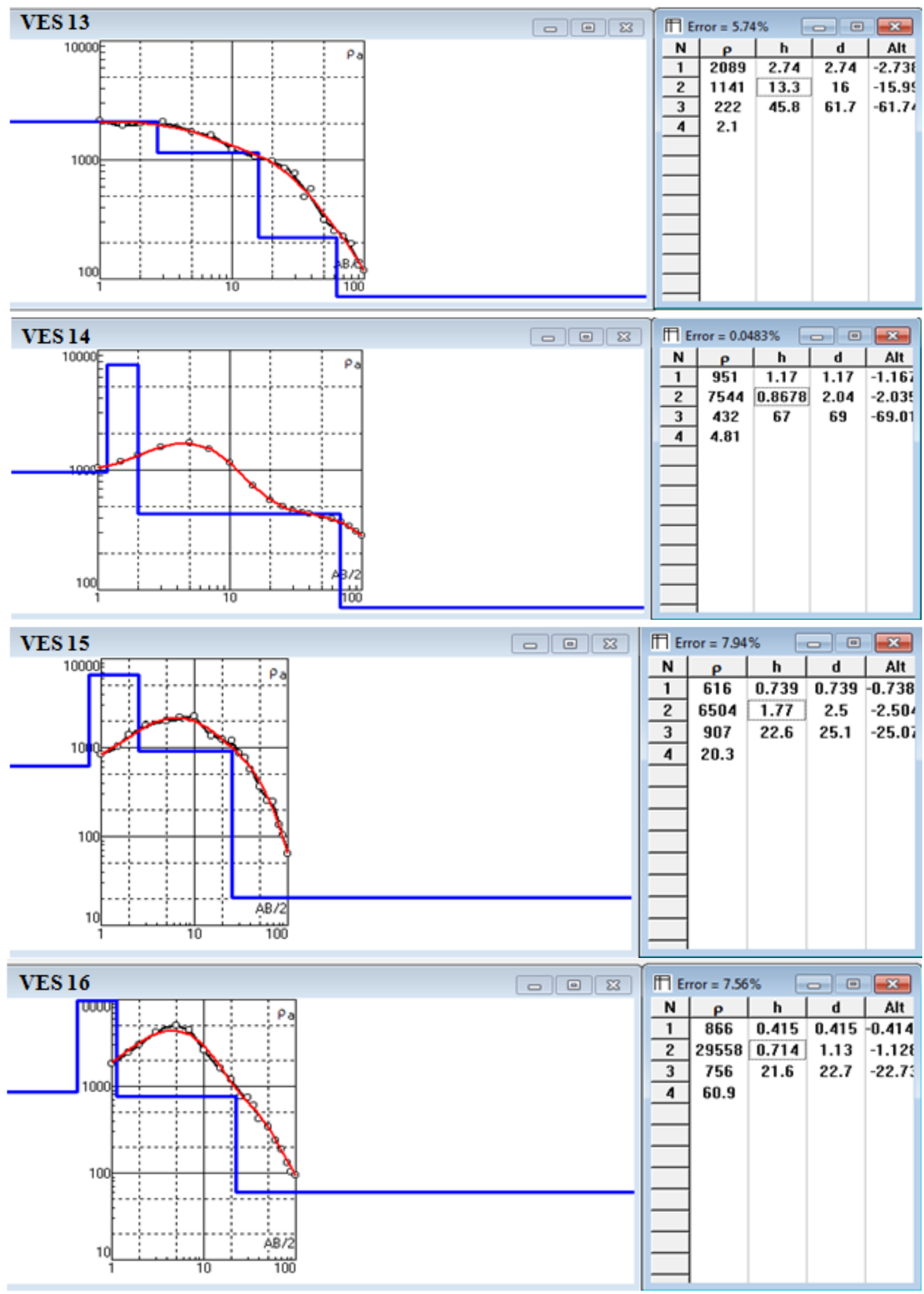

Appendix Figure 1 Contd. Model VES curves of 4 locations VES 13 - VES 16. 


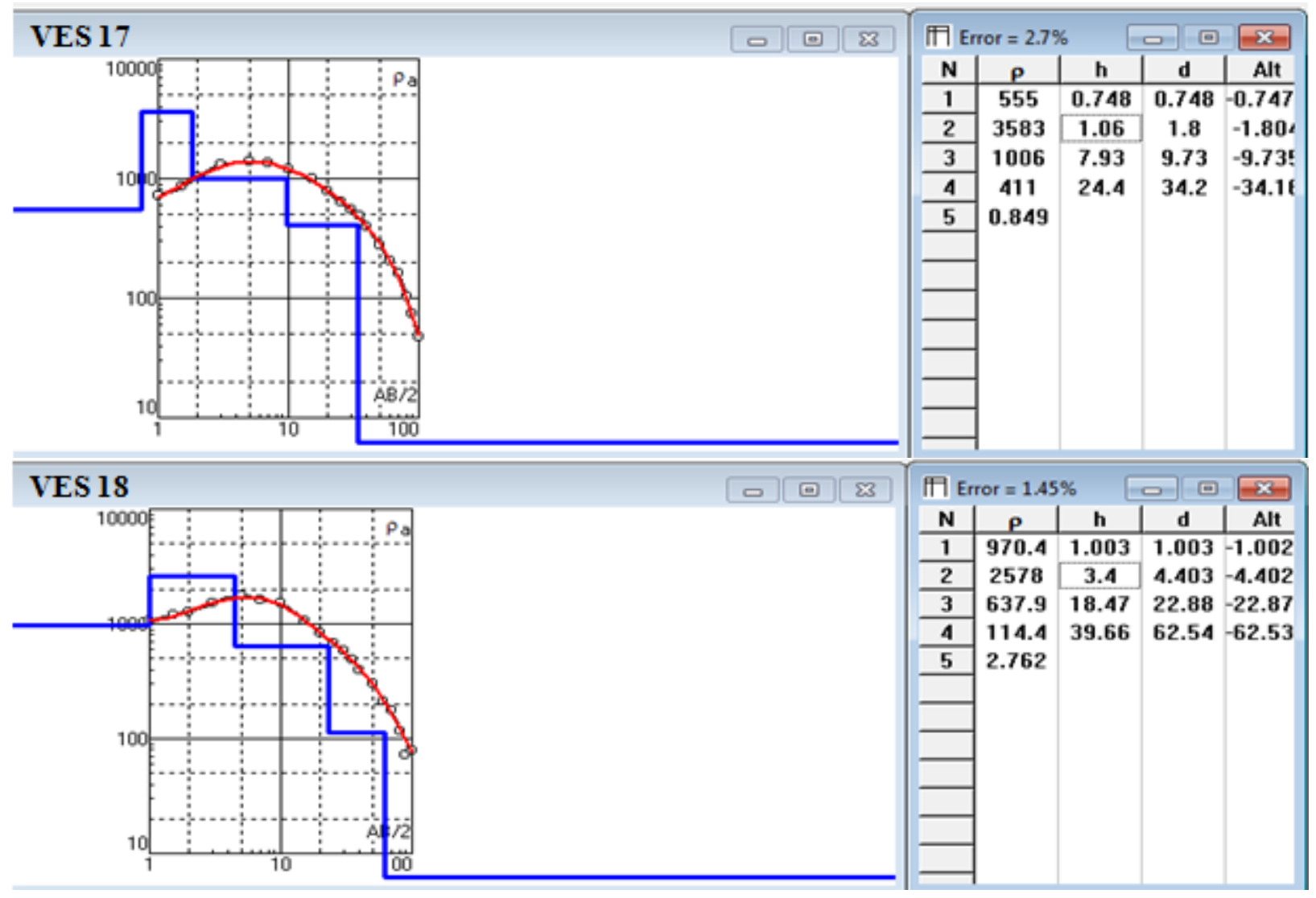

Appendix Figure 1 Contd. Model VES curves of 4 locations VES 17 - VES 18. 